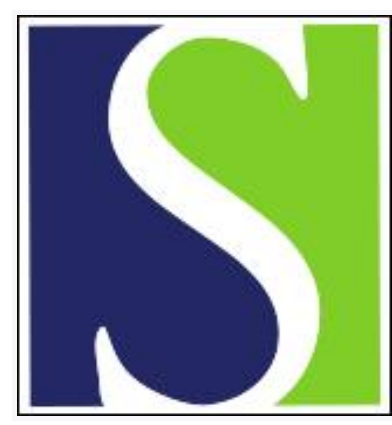

Scand J Work Environ Health 1984;10(2):89-93

https://doi.org/10.5271/sjweh.2353

Issue date: Apr 1984

Chronic effects of trichloroethylene upon S-100 protein content and lipid composition in gerbil cerebellum.

by Kyrklund T, Goracci G, Haglid KG, Rosengren L, Porcellati G, Kjellstrand $P$

The following article refers to this text: 1986;12(2):154-155

This article in PubMed: www.ncbi.nlm.nih.gov/pubmed/6474106

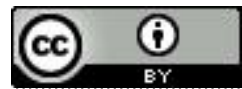




\title{
Chronic effects of trichloroethylene upon S-100 protein content and lipid composition in gerbil cerebellum
}

\author{
by Titus Kyrklund, BA, ${ }^{1}$ Gianfrancesco Goracci, PhD, ${ }^{2}$ Kenneth G Haglid, MD, ${ }^{1}$ \\ Lars Rosengren, $\mathrm{BM},{ }^{1}$ Giuseppe Porcellati, MD, ${ }^{2}$ Per Kjellstrand, $\mathrm{PhD}^{3}$
}

\begin{abstract}
KYRKLUND T, GORACCI G, HAGLID KG, ROSENGREN L, PORCELLATI G, KJELLSTRAND $P$. Chronic effects of trichloroethylene upon S-100 protein content arid lipid composition in gerbil cerebellum. Scand J Work Environ Health 10 (1984) 89-93. Gerbil rats were exposed to trichloroethylene (TCE) vapors intermittently $(8 \mathrm{~h} / \mathrm{d})$ at $510 \mathrm{ppm}$ or continuously at $170 \mathrm{ppm}$ for five months. The cerebellar content of S-100 protein and the phospholipid fatty-acid profiles were determined. S-100 protein, a possible marker for astrocytic reactivity, indicated delayed astrocytic reactivity in the anterior cerebellar hemisphere and a decrease of S-100 protein in the posterior cerebellar vermis. Minor lipid changes were observed. The fatty-acid profiles of ethanolamine phosphoglycerides showed a tendency towards alterations among the 22-carbon fatty acids, with a decrease in 22:5 $(\mathrm{N}-3)$, similar to those shown earlier for cerebral cortex and hippocampus of the gerbil. Two monoenoic fatty acids were decreased, the 20:1 of phosphatidyl-ethanolamine and the 18:1 of the phosphatidyl-serine. This occurrence could indicate a decrease in myelin in areas where these two fatty acids were found to be enriched.
\end{abstract}

Key terms: acyl group composition, chronic exposure, fatty-acid composition, glial proteins, organic solvents.

Trichloroethylene (TCE), a chlorinated aliphatic hydrocarbon, is one of the most commonly used organic solvents in industry. For example, it is used in degreasing, as a glue component, and as a cleaning agent.

The potential hazards of TCE exposure to man have been investigated previously $(6,14,20,23)$. Although there exists a well-known depressant effect on the central nervous system and several reports describe fatigue, headache, and loss of memory, clear evidence of alterations in the nervous system are few (7, $8,11)$ except after exposure to very high doses $(3,16)$.

Organic solvents are thought to have their anesthetic effects on neural membranes, in particular by their interaction with membrane lipids $(5,19)$. In this report we present data on the cholesterol levels, phospholipid composition, and fatty-acid distribution of four major phospholipid classes in the Mongolian gerbil cerebellum. The animals were chronically exposed to TCE for five months to examine whether lipid alterations might develop. A recent

\footnotetext{
1 Institute of Neurobiology, University of Göteborg, S-400 33 Göteborg, Sweden.

2 Istituto di Chimica Biologica, Università di Perugia, I-06100 Perugia, Italy.

3 Institute of Zoophysiology, University of Lund, S-233 62 Lund, Sweden.
}

Reprint requests to: $\mathrm{Mr} \mathrm{T}$ Kyrklund, Institute of Neurobiology, University of Göteborg, Box 33031, S-400 33 Göteborg, Sweden. publication from our laboratory reported fatty-acid changes in gerbil cerebrum after long-term exposure to low doses of TCE (13).

The soluble protein S-100 has been presented as a useful tool in the study of glial reactivity after exposure to chlorinated organic solvents $(7,8)$, and pronounced gliosis could be suspected to give lipid changes. Consequently the concentration of S-100 in different regions of the cerebellum was investigated.

\section{Methods}

Mongolian gerbils were exposed to TCE vapors in an inhalation chamber. A description of the exposure procedure has previously been published (8). This chronic five-month experiment was designed to compare continuous 24-h exposure with intermittent exposure ( $8 \mathrm{~h}$ of exposure $\& 16 \mathrm{~h}$ of nonexposure). The TCE vapor concentration in the continuous exposure group was $170 \mathrm{ppm}$ and in the 8 -h intermittent group $510 \mathrm{ppm}$. Therefore, the average exposure throughout 24-h was the same in both TCE-exposed groups. Animals exposed to air in identical chambers served as a control group.

For the determination of the S- 100 protein, the animals were decapitated, whereafter the cerebellums were rapidly extirpated and dissected into four discrete regions (8). The tissue samples were weighed and frozen at $-80^{\circ} \mathrm{C}$ until analyzed. A soluble pro- 
tein fraction was extracted in a $0.1 \mathrm{M}$ barbital buffer (pH 7.6) according to described procedures (8). The S-100 protein quantitation was carried out with rocket immunoelectrophoresis according to Stavrou et al (21).

The animals for the lipid analyses were killed by decapitation, and the heads were immediately subjected to focused microwave irradiation $(2,450 \mathrm{~Hz}$, $2,400 \mathrm{~W}, 1.39 \mathrm{~s}$ ) prior to dissection of the cerebellums.

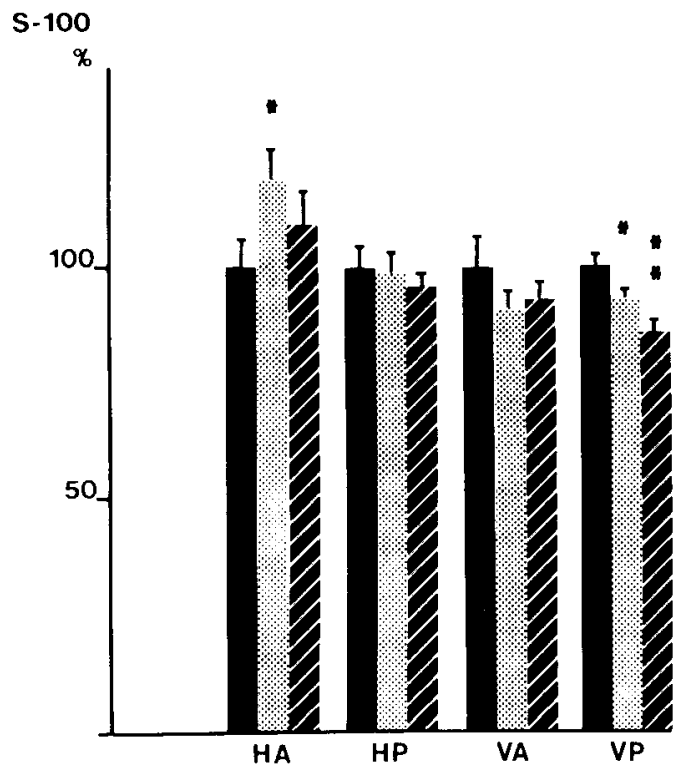

Control $\square$; TCE exposure: $170 \mathrm{ppm}$, intermittent 2

Figure 1. S-100 protein ( $\mathrm{mg} / \mathrm{g}$ wet weight) in the anterior hemisphere (HA), posterior hemisphere (HP), anterior vermis (VA), and posterior vermis (VP) of gerbil cerebellum as the percentage of the corresponding control value (" $p<0.05$ \& $* \star p<0.01$ as compared to the control value).
The cerebellums were weighed, frozen on dry ice, and stored at $-40^{\circ} \mathrm{C}$.

Three frozen cerebellums were pooled and extracted in chloroform/methanol (2:1) according to Folch-Pi et al (4). The chloroform contained $0.1 \%$ 2,6-di-tert-butyl-p-cresol, as an antioxidant. The lipid extract was passed through a 10 -g silic acid column (inner diameter $1 \times 30 \mathrm{~cm}$ ), neutral lipids being eluted with $125 \mathrm{ml}$ of chloroform/methanol (98:2) and polar lipids with $125 \mathrm{ml}$ of methanol (18). The resulting extracts were taken to dryness on a rotatory evaporator. Cholesterol and lipid phosphorus were determined according to Zlatkis et al (24) and Ernster et al (2). Two-dimensional thin-layer chromatography was performed to separate individual phospholipids (10). Spots were visualized and scraped off for phosphorous determination, the individual phospholipid content thus being provided (2). For analysis of the fatty-acid composition, individual phospholipids were again separated as already described. Methyl esters of the scraped spots were prepared (18), and gas chromatographic analysis was carried out on a $1.8-\mathrm{m}$ packed column using $10 \%$ SP-2330 on Chromosorb WAW (Supelco) at $190^{\circ} \mathrm{C}$ (18). Peak areas were calculated by electronic integration. Each sample was run in duplicate.

The statistical treatment of the lipid results was performed with the analysis of variance, which was followed by the least significant difference test for $F$ values giving a probability of $<0.05(15)$. S-100 protein was analyzed as the percentage of the control levels by Fisher's permutation test (17).

\section{Results}

There was no significant difference in the weight of the pooled cerebellums of the control and solventtreated groups [controls 0.433 (SD 0.023 ) g, continu-

Table 1. Lipid composition ( $\mu \mathrm{mol} / \mathrm{g}$ wet weight) in gerbil cerebellum exposed to trichloroethylene (TCE) (170 ppm continuously or $510 \mathrm{ppm}$ intermittently for five months)

\begin{tabular}{|c|c|c|c|c|c|c|}
\hline \multirow{2}{*}{ Lipid class } & \multicolumn{2}{|c|}{$\begin{array}{l}\text { Control } \\
(\mathrm{N}=4)\end{array}$} & \multicolumn{2}{|c|}{$\begin{array}{l}\text { Continuous TCE } \\
\text { exposure }(\mathrm{N}=4) \\
\end{array}$} & \multicolumn{2}{|c|}{$\begin{array}{l}\text { Intermittent TCE } \\
\text { exposure }(\mathrm{N}=4) \\
\end{array}$} \\
\hline & Mean & SD & Mean & SD & Mean & SD \\
\hline Cholesterol & 35.5 & 2.82 & 39.3 & 5.10 & 39.2 & 2.59 \\
\hline Total lipid phosphorus & 58.8 & 2.43 & 59.5 & 1.30 & 58.3 & 0.81 \\
\hline Phosphatidyl-ethanolamine & 9.7 & 0.23 & 10.3 & $0.19^{* *}$ & 9.8 & 0.21 \\
\hline Ethanolamine plasmalogen & 13.7 & 0.74 & 13.6 & 0.48 & 13.3 & 0.61 \\
\hline Phosphatidyl-choline & 21.3 & 1.32 & 21.6 & 0.36 & 21.3 & 0.76 \\
\hline Choline plasmalogen & 0.9 & 0.18 & 0.9 & 0.17 & 0.9 & 0.33 \\
\hline Phosphatidyl-inositol & 2.0 & 0.12 & 1.9 & 0.12 & 1.9 & 0.05 \\
\hline Sphingomyelin & 3.7 & 0.24 & 3.7 & 0.28 & 3.6 & 0.31 \\
\hline Phosphatidyl-serine & 7.7 & 0.54 & 7.5 & 0.90 & 7.6 & 0.27 \\
\hline $\begin{array}{l}\text { Ethanolamine plasmalogen as percentage } \\
\text { of the total ethanolamine phosphoglyceride }\end{array}$ & 58.4 & 0.96 & 56.8 & 1.13 & 57.6 & 1.36 \\
\hline
\end{tabular}

* $p<0.01$ as compared to control. 
ously exposed 0.400 (SD 0.026) g, intermittently exposed 0.410 (SD 0.027) g]. S-100 protein per wet weight of tissue showed an increase in the anterior hemispheres after continuous exposure to TCE (figure 1). The corresponding levels of the posterior hemispheres and the anterior part of the cerebellar vermis were however similar to the control values. The posterior part of the cerebellar vermis of the exposed groups showed a decreased S-100 content in comparison to that of the controls (figure 1).

In whole cerebellum, the concentrations of the individual phospholipids were approximately the same in all the groups with respect to TCE exposure. Phosphatidyl-ethanolamine showed a small but significant increase $(p<0.01)$ in the group continuously exposed to $170 \mathrm{ppm}$ of TCE (table 1). The total lipid phosphorous and cholesterol contents were unchanged.

The fatty-acid pattern of the main phospholipid classes was similar among the different groups of animals (tables 2-5). However, the 22:5 (N-3) content in ethanolamine plasmalogen, the $20: 1$ in phosphatidyl-ethanolamine, and the 18:1 in phosphatidyl-serine were all decreased in the continuously exposed group in comparison to the corresponding values of the controls (tables 2, 3 \& 5).

\section{Discussion}

The levels of exposure to TCE in this study were below the anesthetic level. Since it was reported recently (12) that exposure to TCE vapor for five to nine months induces signs of adaptation, we chose a similar experimental period.

The glial protein S-100 has been shown to be affected by chlorinated organic solvents. This phenomenon was shown both after various lengths of exposure (up to eight weeks) and after the animals were allowed to recover at the end of exposure $(7,8)$. In a previous study the S-100 protein was shown to increase initially in several regions of the gerbil brain during the first four weeks of exposure. After eight weeks of exposure the S-100 protein declined to near control values (8).

Table 2. Fatty acid composition of phosphatidyl-ethanolamine ( $\mathrm{mol} \%$ ) in gerbil cerebellum exposed to trichloroethylene (TCE) (170 ppm continuously or $510 \mathrm{ppm}$ intermittently for five months).

\begin{tabular}{|c|c|c|c|c|c|c|}
\hline \multirow{2}{*}{ Fatty acid } & \multicolumn{2}{|c|}{$\begin{array}{l}\text { Control } \\
(N=4)\end{array}$} & \multicolumn{2}{|c|}{$\begin{array}{l}\text { Continuous TCE exposure } \\
(N=4)\end{array}$} & \multicolumn{2}{|c|}{$\begin{array}{l}\text { Intermittent TCE exposure } \\
\qquad(N=4)\end{array}$} \\
\hline & Mean & $\mathrm{SD}$ & Mean & $\mathrm{SD}$ & Mean & $\mathrm{SD}$ \\
\hline $16: 0$ & 7.92 & 0.16 & 8.20 & 0.30 & 8.28 & 0.42 \\
\hline $16: 1$ & 0.59 & 0.01 & 0.74 & 0.18 & 0.57 & 0.03 \\
\hline 18:0 & 29.75 & 0.50 & 29.52 & 0.56 & 30.06 & 1.86 \\
\hline $18: 1$ & 17.35 & 0.28 & 17.47 & 1.53 & 17.84 & 0.72 \\
\hline $18: 2$ & 1.64 & 0.15 & 2.01 & 0.39 & 1.64 & 0.64 \\
\hline $18: 3$ & 0.18 & 0.09 & 0.24 & 0.03 & 0.16 & 0.09 \\
\hline $20: 1$ & 1.63 & 0.12 & 1.43 & $0.11^{*}$ & 1.58 & 0.08 \\
\hline $20: 3(N-6)$ & 0.48 & 0.16 & 0.48 & 0.16 & 0.44 & 0.08 \\
\hline $20: 4(N-6)$ & 9.59 & 0.27 & 9.33 & 0.72 & 9.78 & 0.25 \\
\hline $20: 5(\mathrm{~N}-3)$ & 0.08 & 0.04 & 0.06 & 0.04 & 0.09 & 0.04 \\
\hline $22: 4(\mathrm{~N}-6)$ & 1.96 & 0.08 & 2.03 & 0.18 & 2.05 & 0.19 \\
\hline $22: 5(N-6)$ & 0.35 & 0.04 & 0.40 & 0.08 & 0.34 & 0.03 \\
\hline $22: 5(\mathrm{~N}-3)$ & 0.22 & 0.05 & 0.22 & 0.03 & 0.21 & 0.02 \\
\hline 22:6 $(\mathrm{N}-3)$ & 28.21 & 0.67 & 27.85 & 2.02 & 27.35 & 2.14 \\
\hline
\end{tabular}

* $p<0.05$ as compared to control.

Table 3. Fatty acid composition of ethanolamine plasmalogen (mol \%) in gerbil cerebellum exposed to trichloroethylene (TCE) (170 ppm continuously or $510 \mathrm{ppm}$ intermittently for five months).

\begin{tabular}{|c|c|c|c|c|c|c|}
\hline \multirow{2}{*}{ Fatty acid } & \multicolumn{2}{|c|}{$\begin{array}{l}\text { Control } \\
(N=4)\end{array}$} & \multicolumn{2}{|c|}{$\begin{array}{l}\text { Continuous TCE exposure } \\
\qquad(N=4)\end{array}$} & \multicolumn{2}{|c|}{$\begin{array}{l}\text { Intermittent TCE exposure } \\
\qquad(\mathbf{N}=4)\end{array}$} \\
\hline & Mean & $\mathrm{SD}$ & Mean & SD & Mean & SD \\
\hline $16: 0$ & 4.20 & 0.30 & 4.44 & 0.54 & 4.28 & 0.37 \\
\hline $16: 1$ & 1.44 & 0.21 & 1.65 & 0.31 & 1.34 & 0.14 \\
\hline 18:0 & 1.51 & 0.42 & 1.17 & 0.16 & 1.52 & 0.30 \\
\hline $18: 1$ & 35.23 & 0.56 & 35.07 & 1.81 & 34.09 & 0.98 \\
\hline $18: 2$ & 1.87 & 0.35 & 2.06 & 0.63 & 1.72 & 0.29 \\
\hline $18: 3$ & 0.47 & 0.14 & 0.47 & 0.23 & 0.37 & 0.16 \\
\hline $20: 1$ & 8.25 & 0.60 & 8.03 & 0.51 & 8.00 & 0.41 \\
\hline $20: 3(N-6)$ & 0.99 & 0.04 & 1.09 & 0.24 & 1.09 & 0.12 \\
\hline $20: 4(N-6)$ & 11.97 & 0.47 & 12.05 & 0.87 & 12.49 & 0.52 \\
\hline $20: 5(\mathrm{~N}-3)$ & 0.20 & 0.04 & 0.15 & 0.07 & 0.15 & 0.06 \\
\hline $22: 4(N-6)$ & 4.78 & 0.35 & 4.87 & 0.32 & 4.80 & 0.37 \\
\hline $22: 5(N-3)$ & 0.62 & 0.04 & 0.55 & $0.33^{\star}$ & 0.59 & 0.01 \\
\hline $22: 6(N-3)$ & 28.72 & 1.29 & 28.39 & 2.39 & 29.60 & 0.59 \\
\hline
\end{tabular}

* $p<0.05$ as compared to control. 
Table 4. Fatty acid composition of phosphatidyl-choline ( $\mathrm{mol} \%)$ in gerbil cerebellum exposed to trichloroethylene (TCE) (170 ppm continuously or $510 \mathrm{ppm}$ intermittently for five months).

\begin{tabular}{|c|c|c|c|c|c|c|}
\hline \multirow[t]{2}{*}{ Fatty acid } & \multicolumn{2}{|c|}{$\begin{array}{l}\text { Control } \\
(N=4)\end{array}$} & \multicolumn{2}{|c|}{$\begin{array}{l}\text { Continuous TCE exposure } \\
\qquad(N=4)\end{array}$} & \multicolumn{2}{|c|}{$\begin{array}{l}\text { Intermittent TCE exposure } \\
\qquad(N=4)\end{array}$} \\
\hline & Mean & $\mathrm{SD}$ & Mean & SD & Mean & SD \\
\hline $16: 0$ & 23.26 & 1.65 & 22.75 & 1.30 & 23.75 & 2.38 \\
\hline $16: 1$ & 1.45 & 0.16 & 1.40 & 0.11 & 1.47 & 0.15 \\
\hline 18:0 & 17.23 & 0.42 & 17.58 & 0.62 & 17.24 & 0.93 \\
\hline 18:1 & 34.45 & 0.57 & 34.66 & 0.45 & 34.07 & 0.51 \\
\hline 18:2 & 3.14 & 0.04 & 3.15 & 0.41 & 2.97 & 0.16 \\
\hline $18: 3$ & 0.31 & 0.08 & 0.25 & 0.07 & 0.25 & 0.05 \\
\hline $20: 1$ & 1.66 & 0.14 & 1.58 & 0.05 & 1.80 & 0.30 \\
\hline $20: 3(N-6)$ & 0.48 & 0.02 & 0.43 & 0.04 & 0.45 & 0.05 \\
\hline $20: 4(N-6)$ & 5.48 & 0.39 & 5.51 & 0.35 & 5.65 & 0.30 \\
\hline $20: 5(N-3)$ & 0.65 & 0.15 & 0.83 & 0.40 & 0.67 & 0.12 \\
\hline $22: 4(N-6)$ & 0.68 & 0.13 & 0.65 & 0.08 & 0.78 & 0.12 \\
\hline $22: 5(\mathrm{~N}-6)$ & 0.55 & 0.12 & 0.52 & 0.17 & 0.56 & 0.13 \\
\hline $22: 5(\mathrm{~N}-3)$ & 0.12 & 0.05 & 0.10 & 0.05 & 0.13 & 0.04 \\
\hline $22: 6(\mathrm{~N}-3)$ & 10.07 & 0.48 & 10.16 & 0.64 & 9.91 & 0.83 \\
\hline
\end{tabular}

Table 5. Fatty acid composition of phosphatidyl-serine (mol \%) in gerbil cerebellum exposed to trichloroethylene (TCE) (170 ppm continuously or $510 \mathrm{ppm}$ intermittently for five months).

\begin{tabular}{|c|c|c|c|c|c|c|}
\hline \multirow{2}{*}{ Fatty acid } & \multicolumn{2}{|c|}{$\begin{array}{l}\text { Control } \\
(N=4)\end{array}$} & \multicolumn{2}{|c|}{$\begin{array}{l}\text { Continuous TCE exposure } \\
\qquad(\mathrm{N}=4)\end{array}$} & \multicolumn{2}{|c|}{$\begin{array}{l}\text { Intermittent TCE exposure } \\
\qquad(N=4)\end{array}$} \\
\hline & Mean & SD & Mean & SD & Mean & $S D$ \\
\hline $16: 0$ & 2.23 & 0.29 & 2.30 & 0.22 & 1.90 & 0.54 \\
\hline $16: 1$ & 0.47 & 0.10 & 0.56 & 0.10 & 0.49 & 0.14 \\
\hline $18: 0$ & 33.67 & 2.09 & 33.87 & 0.76 & 32.74 & 0.76 \\
\hline 18:1 & 26.91 & 0.47 & 25.45 & $0.64^{*}$ & 26.46 & 0.46 \\
\hline $18: 2$ & 1.08 & 0.43 & 1.20 & 0.12 & 1.02 & 0.19 \\
\hline $18: 3$ & 0.40 & 0.14 & 0.37 & 0.10 & 0.47 & 0.13 \\
\hline $20: 1$ & 2.21 & 0.29 & 1.93 & 0.12 & 2.23 & 0.20 \\
\hline $20: 3(N-6)$ & 0.89 & 0.35 & 0.72 & 0.31 & 0.82 & 0.39 \\
\hline $20: 4(N-6)$ & 4.51 & 0.48 & 5.01 & 0.52 & 5.15 & 0.28 \\
\hline $20: 5(\mathrm{~N}-3)$ & 0.28 & 0.10 & 0.43 & 0.19 & 0.41 & 0.20 \\
\hline $22: 4(N-6)$ & 2.64 & 0.20 & 2.69 & 0.34 & 2.78 & 0.22 \\
\hline $22: 5(N-6)$ & 1.53 & 0.32 & 1.32 & 0.14 & 1.30 & 0.11 \\
\hline $22: 5(\mathrm{~N}-3)$ & 0.34 & 0.06 & 0.33 & 0.05 & 0.33 & 0.04 \\
\hline $22: 6(\mathrm{~N}-3)$ & 21.95 & 1.05 & 22.35 & 0.40 & 22.29 & 2.55 \\
\hline
\end{tabular}

* $p<0.05$ as compared to contral.

In the present experiment the exposure level was lower and the exposure time longer than in the previously mentioned study. The S-100 protein was elevated in the cerebellar anterior hemisphere, a brain region that showed no change at shorter periods (8). Moreover we found decreased levels of S-100 protein in the posterior cerebellar vermis after both continuous and intermittent exposure to TCE. This region showed a gradual increase over the first four weeks of TCE exposure $(320 \mathrm{ppm})$, declining again to base levels until week eight (8).

Altered levels of the S-100 protein might reflect glial cell reactivity towards poisoning. Moreover a differential sensitivity of the glial cell S-100 protein has been shown in different brain regions upon exposure to organic solvents $(7,8)$. Consequently the increased S-100 protein concentration in the cerebellar anterior hemisphere can indicate delayed glial cell reactivity and, therefore, reflect lower sensitivity towards TCE poisoning in comparison to that observed in the posterior cerebellar vermis. In this cerebellar region, the initial increase in S-100 protein during the first weeks of exposure changed to a decrease when a longer experimental period was used (8). The initial dynamic changes in the content of S-100 protein appeared to stabilize in this long-term experiment, and the decrease observed in the posterior vermis was also evident after three months of exposure followed by a rehabilitation period (7). Any suspected change in the glial population would be so small that it would not possibly affect the lipid composition under the present conditions. Changes in the S-100 protein levels could, in part, also reflect organic solvent-induced alterations in protein-membrane in teractions (8), since calcium-induced binding of S-100 protein to membranes has been demonstrated (1).

Exposure to TCE showed no pronounced effects on the lipid class concentrations. An increased concentration of phosphatidyl-ethanolamine was noted in the continuously exposed group, and a tendency towards a reduction in the relative amount of ethanolamine plasmalogen was observed in both exposed groups. Such changes could not be satisfactorily explained. 
The small changes observed among the 22-carbon highly polyunsaturated fatty acids in ethanolamine phosphoglycerides (tables 2 \& 3) were in agreement with, but lower than, those observed for cerebral cortex and hippocampus after 12 months' exposure to TCE (150 ppm) (13). The present observation with decreased 22:5 (N-3) was a persistent finding. The long-chain polyunsaturated fatty acids did not seem to be affected in phosphatidyl-choline and phosphatidyl-serine in the same manner as in ethanolamine phosphoglycerides.

The whole cerebellum contained a larger amount of white matter. This phenomenon was evidenced by a higher content of ethanolamine plasmalogen and monoenoic fatty acids in comparison to that observed in cerebral cortex and hippocampus of the gerbil (13). One alternative is that the long-chain highly polyunsaturated fatty acids could be less sensitive to change after TCE exposure in whole cerebellum than in cerebral cortex and hippocampus. More likely, alterations in the highly polyunsaturated fatty acids occur largely in the gray matter and, therefore, were less pronounced in this experiment concerning whole cerebellum. On the other hand, a decrease in phosphatidyl-ethanolamine $20: 1$ and phosphatidyl-serine 18:1 was found, two fatty acids that are found in high proportions in myelin $(9,22)$. This finding could indicate a small decrease in myelin content.

Exposure to TCE vapor induces minor changes in lipid class concentrations and fatty-acid distribution in gerbil cerebellum. Long-chain, highly polyunsaturated fatty acids in ethanolamine phosphoglycerides seemed to be affected, as well as the monoenes.

Intermittent $(8 \mathrm{~h} / \mathrm{d})$ exposure appears to have less effect than continuous exposure $(24 \mathrm{~h} / \mathrm{d})$ or may, to a greater extent, induce protective mechanisms towards injury.

\section{Acknowledgment}

This work has been supported by grants from the Swedish Work Enviroment Fund (no 80-0127).

\section{References}

1. Donato R, Michetti F, Miani N. Soluble and membrane bound S-100 protein in cerebral cortex synaptosoms: Properties of the S-100 receptor. Brain Res 98 (1975) $561-573$.

2. Ernster L, Zetterström R, Lindberg O. Method for the determination of tracer phosphate in biological material. Acta Chem Scand 4 (1950) 942-947.

3. Feldman RG, Mayer RM, Taub A. Evidence for peripheral neurotoxic effect of trichloroethylene. Neurology $20(1970) 599-606$.

4. Folchi-Pi J, Lees M, Sloane-Stanley GH. A simple method for the isolation and purification of total lipids from animal tissues. J Biol Chem 226 (1957) 497-509.
5. Franks NP, Lieb WR. Where do general anaesthetics act? Nature 274 (1978) 339-342.

6. Grandjean E, Munchinger R, Turrain V, Haas PA, Knoppel HK, Rosenmund H. Investigations into the effects of exposure to trichloroethylene in mechanical engineering. $\mathrm{Br} \mathrm{J}$ Ind Med 12 (1955) 131-142.

7. Haglid KG, Briving C, Hansson H-A, Kjellstrand $P$, Rosengren L, Stavrou D, Swedin U, Wronski A. Trichloroethylene: Long-lasting changes in the brain after rehabilitation. Neurotoxicology 4 (1981) 59-67.

8. Haglid $\mathrm{KG}$, Kjellstrand $\mathrm{P}$, Rosengren L, Wronski A, Briving C. Effects of trichloroethylene inhalation on proteins of the gerbil brain. Arch Toxicol 43 (1980) $187-199$.

9. Hamberger A; Svennerholm L. Composition of gangliosides and phospholipids of neuronal and glial cell enriched fractions. J Neurochem 18 (1971) 18211829.

10. Horrocks LA, Sun GY. Ethanolamine plasmalogens. In: Marks N, Rodnight $\mathrm{R}$, ed. Research methods in neurochemistry. Volume 1. Plenum Press, New York, NY 1972, pp 223-231.

11. Huff JE. New evidence on the old problems of trichloroethylene. Ind Med Surg 40 (1971): 8, 25-33.

12. Kjellstrand $P$, Lanke $J$, Bjerkemo $M$, Zetterqvist $L$, Månsson L. Irreversible effects of trichloroethylene exposure on the central nervous system. Scand J Work Environ Health 6 (1980) 40-47.

13. Kyrklund $T$, Alling $C$, Haglid $K G$, Kjellstrand $P$. Chronic exposure to trichloroethylene: Lipid and acyl group composition in gerbil cerebral cortex and hippocampus. Neurotoxicology 4 (1983): 4, 35-42.

14. Langauer-Lewowicka H, Manskova T, DobrogowskaKunicha J. Assessment of the state of nervous system in subjects exposed to organic solvents [in Polish with English summary]. Neurol Neurochir Pol VIII 8: 24 (1974): 4, 563.

15. Miller RG. Simultaneous statistical interference. McGraw Hill, New York, NY 1966.

16. Mitchell ABS, Parsons-Smith BG. Trichloroethylene neuropathy. Br Med J 1 (1969) 422-423.

17. Odén A, Wedel H. Arguments for Fischer's permutation test. Ann Stat 3 (1975) 518-520.

18. Porcellati G, De Medico GE, Fini C, Floridi A, Goracci G, Horrocks LA, Lazarewicz JW, Palmerini CA, Strosznajder J, Trovarelli G. Phospholipid and its metabolism in ischemia. In: Neuhoff $\mathrm{V}$, ed. Proceedings of the European Society for Neurochemistry. Volume 1. Verlag Chemie Weinheim, New York, NY 1978, pp $285-302$.

19. Seeman P. The membrane actions of anesthetics and tranquilizers. Pharmacol Rev 24 (1972) 583-655.

20. Smith GF. Trichloroethylene: A review. Br J Ind Med 23 (1966) 249-262.

21. Stavrou D, Lübbe I, Haglid KG. Immunoelektrophoretische Quantifizierung des Hirnspezifischen S-100 Proteins. Acta Neuropathol 29 (1974) 275-280.

22. Sun AY, Sun GY. Functional roles of phospholipids of synaptosomal membrane. Adv Exp Med Biol 72 (1976) 169-197.

23. Waters EM, Gerstner HB, Huff JE. Trichloroethylene: I An overview. J Toxicol Environ Health 2 (1977) $671-701$.

24. Zlatkis A, Zak B, Boyle AJ. A new method for the direct determination of serum cholesterol. J Lab Clin Med 41 (1953) 486-492.

Received for publication: 7 December 1983 